\title{
ИСЛАМСКИЙ БАНКИНГ КАК УГРОЗА ДУХОВНОЙ БЕЗОПАСНОСТИ СВЕТСКОГО ГОСУДАРСТВА
}

\begin{abstract}
Аннотация. Статья посвящена перспективам развития исламского банкинга на территории стран СНГ, где в последнее время превалирует мнение о «полезности» исламских банков в условиях мирового финансового кризиса.Автор приходит к выводу о том, что главным инструментом реализации иелей исламского мирового порядка выступают исламские банки, выступая в качестве действенного инструмента влияния и давления в зоне распространения ислама в цеелях реализаџии конщепциии исламского мирового порядка, что приведет к угрозе духовной безопасности государства, являющейся неотьемлемой частью национальной и конституционной безопасности. Автор уверен, что реализация концеепции исламского мирового порядка, где одной из претензий на мировое господство ислама является вторжение его в основы экономической жизни, угрожает светским принципам миропонимания и светскому праву в России, т.к. может нанести непоправимый ущерб гражданскому обществу и демократии в Российской Федерациии.

Ключевые слова: банкинг, ислам, духовная безопасность, светскость, религия, демократия, право, свобода совести, экспансия, исламизащия.
\end{abstract}

«Люди всегда были и всегда будут глупенькими жсертвами обмана и самообмана в политике, пока они не научатся за любыми нравственными, религиозными, политическими, социальными фразами, заявлениями, обещаниями разыскивать интересы тех или иных классов"

Ленин В. И. Три источника и три составных части марксизма

// (Полн. собр. соч.- Т. 23.-С. 47)

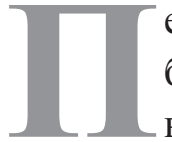
ерспективы развития исламского банкинга на территории стран СНГ в последнее время интересуют и волнуют многих.

В России в условиях ещё до финансового кризиса интерес к исламскому банкингу в самых различных кругах повысился, несмотря на то, что отзыв Центробанком лицензии в декабре 2006 года у единственного на то время банка, позиционировавшего себя как исламский банк «Бадр-Форте» банка, повлёк череду высказываний о том, что в России исламский банкинг - едва ли сможет полноценно воплотиться на практике, однако с наступлением кризиса интерес к исламскому банкингу в России ещё более возрос 1 .

За последние двадцать лет религиозной свободы появились тысячи статей, проведены сотни конференций и семинаров, защищены сотни кандидатских и докторских диссертаций, ставящие целью доказать, что религия, и ислам в особенности, есть совокупность высоких общечеловеческих идеалов, моральных принципов и норм. Все подобные публикации множества маститых авторов

\footnotetext{
${ }^{1}$ http://www.muslimeco.ru/opubl/54/
} 
полны беспардонного расцвечивания ислама самыми привлекательными красками ${ }^{1}$.

В последнее время даже в среде российских ученых, как ни странно, превалирует мнение о «полезности» исламских банков в условиях мирового финансового кризиса.

Очевидно, это связано с тем, что благодаря действующей власти наша страна стала неконкурентоспособным государством в мире и превращается на глазах в третьеразрядную страну.

Поэтому, во имя истины и искренне уважая религиозные чувства мусульман, постараюсь объективно раскрыть вопросы деятельности исламского банкинга.

При этом, раскрывая его деятельность в своей статье, автор не видит необходимости обсуждения правосознания и религиозного сознания в исламе, хотя ислам как мировая религия и занимает в настоящее время второе место в мире, после христианства,по числу своих приверженцев.

Автор не дает определение формам общественного сознания, которые являются традиционными для современной философской и юридической теории, не говорит о связи правового и религиозного сознания, проблемах теории и деформации правосознания, т. к. уже существует множество работ на заданную тему².

\footnotetext{
${ }^{1}$ См. например статью ведущего научного сотрудника НИИ Академии Генеральной прокуратуры РФ Е.В. Быковой «Ислам, мусульманское право и общечеловеческие ценности» (журнал «Международное публичное и частное право», М., 2010. № 4).

${ }^{2}$ См. например: Зыкова С. В. Связь религиозного и правового сознания / С. В. Зыкова //История государства и права. 2006.- № 9.- С.17-19. Корнев В. Н., Проблемы теории правосознания в современной отечественной юриспруденции. История государства и права № 202009., Ковалев С. А. Деформация правосознания как фактор противоправного поведения личности / С. А. Ковалев // История государства и права.— 2009.— N 13.С.35-37., Марченя, П.П. Массовое правосознание как фактор русской революции 1917 г. / Марченя П. П. // История государства и права._-2010.- N 19.-С. 20-22. Право - Общая теория права.
}

Среди российских мусульман, а теперь и некоторых ученых появился устойчивый миф о том, что в России «осущеествляется попьтка противопоставить Православное христианство и Ислам, столкнув их в открытом, в том числе вооружённом, противостоянии» ${ }^{3}$, забывая о том, что, признавая истиной только веру в «своего бога», любая религия считает остальные вероисповедания в лучшем случае ошибочными. А то и прямо враждебными, а потому не чурается открытых призывов уничтожать неверных.

Достаточно вспомнить о джихаде. Или известные в истории России еврейские погромы, антисемитизм, гонения на еретиков и старообрядцев, их четвертование и сожжение. Современное шельмование и преследование на бытовом и законодательном уровне по инициативе РПЦ так называемых иноверцев и сектантов. Вся эта межрелигиозная вражда является существенным негативным фактором, мешающим сближению этнонациональных общностей, а подчас и развитию межгосударственных отношений.

Однажды Гегель обронил замечательную фразу о том, что изучение любого объекта начинается с исследования его генезиса, и это хорошо сделал один из лучших западных историков-востоковедов Бернард Льюис: «Чтобы подчеркнуть вызов христианству, халиф впервые начал чеканить золотыле монеты, что являлось прерогативой римских императоров. Важно отметить, что первые исламские золотые монеты назывались динарами - производными от римского denarius. На некоторых монетах было вылбито имя халифа, его титул - Предводитель вер-

\footnotetext{
3 Тонконогов А.В., автореферат диссертации на диссертации на соискание учёной степени доктора философских наук «Духовная безопасность российского общества в условиях современного геополитического соперничества (социально-философский анализ), М.:, 2011.
} 
ных... С точки зрения мусульман, евреи, а позднее христиане сбились с верного пути и следуют ложным доктринам. Обе религии были замещуены исламом - последним совершенным откровением. Было ещуе одно послание, от омейядского халифа Абд аль-Малика императору Свящуенной Римской империи Оттону I: «Твоя вера извращуена, твое время прошло. Отныне я являюсь правителем Божественной империи на земле». Смысл этого был понятен очень хорошо, и император счел чеканку золотых монет халифом поводом для начала войны. В течение тылсячи лет борьба велась исламскими халифами из столицуы, переносившейся из Мединь в Дамаск, затем в Багдад, Каир и Стамбул, против христианских императоров в Константинополе, Вене и, позднее, против государей, принявиих другие титульг в более далеких западных странах. Каждый из них был в свое время главной изелью джихада»1.

25 сентября 2009 г. исполнилось 40 лет организационного оформления «третьего» пути в мировой политике и экономике - создания в 1969 году Организации Исламская Конференция (ОИК) с сетью ее специализированных учреждений. Начав с 25 государств-учредителей, ОИК в настоящее время насчитывает среди своих членов 57 государств из 191 государства-члена ООН.

Сегодня Организация исламского сотрудничества (ОИС (до 2011 - Организация Исламская конференция (ОИК)); англ. Organisation of Islamic Cooperation (OIC), араб. - международная организация исламских стран является самой крупной и наиболее влиятельной официальной правительственной мусульманской международной организацией.

Практика создания и функционирования специализированных экономических учреждений в рамках ОИК (ОИС) показала, что

\footnotetext{
${ }^{1}$ Бернард Льюис, Кризис ислама, «Bedek Media Ltd.», издание на русском языке, 2007
}

главным инструментом реализации целей исламского мирового порядка выступают исламские банки.

Это связано с двумя обстоятельствами: исламский экономический порядок, задуманный как альтернатива светскому, мог опираться только на экономические возможности стран - участниц движения «Исламская солидарность». Такие возможности имелись исключительно в виде нефтедолларов, а не развитых производительных сил и опыта организации экономики на комплексной основе; кроме того, банки - одно из наиболее эффективных экономических средств дифференцированной политики².

(ОИК) - своего рода ООН мусульманского мира. Она была создана в 1969 г. в противовес неподконтрольной Саудам и слишком «социализирующей» Лиге арабских государств. После ввода советских войск в Афганистан ОИК призвала к «священной войне» с неверным захватчиком, позднее осудила «хомейнизм и шиитский активизм», а в 90-е годы поддерживала мусульман Боснии, Чечни и Косово ${ }^{3}$.

ОИС располагает рядом «технических агентств», главное из которых - Исламский банк развития (создан в 1973 г.).

В частности, после наложения на Пакистан санкций в связи с его ядерными испытаниями этот банк увеличил ему ссуду со \$ 150 млн. до \$ 400 млн. ${ }^{4}$

Часть нефтяной ренты Саудовская Аравия направляет на финансирование 875 исламских

\footnotetext{
2 Жданов Н. В. Исламская концепция миропорядка.- М.: Междунар. Отношения, 2003.- 317 с.

3 Лабевьер Р. Доллары террора: Соединенные штаты и исламисты (LABEVIERE R. Les dollars de la terreur: Les Etats-Unis et les islamistes.- P.: Bernard Grasset, 1999. - 439 р. (Книга главного редактора «Radio France Internationale» посвящена подъему исламизма в мире в 90-е годы и роли в нем ЦРУ США).

${ }^{4}$ Там же.
} 
центров и строительство мечетей по всему миру от Аргентины до Японии и Фиджи, и один из рычагов влияния Саудов в мире - исламские банки, например «Дар-уль-Маль-уль-Исламий» и «Даллах-уль-Барака».

Исламская политика Саудов — чисто оборонительная. По словам одного дипломата, они руководствуются тремя принципами:

1) «прежде всего действовать без шума»; 2) «все можно купить»; 3) «оставьте нас в покое». В этом ключ к их поддержке исламизма ${ }^{1}$.

Теоретики исламского банковского дела критически относятся к принципам функционирования классического «капиталистического» банка, так как деятельность последнего противоречит шариату, запрещающему предоставление денег под проценты, и несовместима с основами «исламской экономики», с ее отношением к распределению богатств и вкладов ${ }^{2}$.

Запрещая «рибаа» (взимание ссудного процента), шариат разрешает «баи» (торговлю) и предоставление средств без взятия процента. Такая норма восходит к суре «Корова» (278-280) Корана:

278 (278) «О вы, которые уверовали! Бойтесь Аллаха и оставьте то, что осталось из роста, если вы верующие».

279 (279) «Если же вы этого не сделаете, то услышите про войну от Аллаха и Его посланника. А если обратитесь, то вам - ваш капитал. Не обижайте, и вы не будете обижены!».

280 (280) «А если кто в тягости, то ожидание до облегчения,- ведь оказать милость - лучше для вас, если вы знаете».

Существует точка зрения, что стих 278 относится к деньгам, оставленным курейшитами у жителей Таифа ${ }^{3}$.

\footnotetext{
${ }^{1}$ Там же.

${ }^{2}$ Piscatori J. P. Islamic Values and National Interest: The Foreign Policy of Saudi Arabia // Islam in Foreign Police.London: Cambridge University Press, 1983._- P. 33.

${ }^{3}$ Валькова Л.В. Саудовская Аравия в международных отношениях — М. Наука, 1979._- С. 165.
}

Глава религиозной общины шиитов в Ираке аятолла Мухаммед Бакир Аль-Садр отмечал, что «исламская банковская система возможна только в условиях мусульманского общества, неотъемлемой частью которого она должна стать» ${ }^{4}$. Чтобы эта система соответствовала исламской философии и идеологии, она должна основываться на следующих принципах:

1) ведущая роль в аккумуляции капитала должна принадлежать государству. Никакие банковские вклады в частные секторы экономики не допускаются;

2) исламское правительство в накоплении банковского капитала не стремится к получению фиксированного процента, а исходит из своей экономической доктрины;

3) запрещаются взятие процента, накопление и трата золота и серебра;

4) утверждение принципа «закята» - отчисление определенного процента в пользу бедных;

5) воспитание в духе ислама, порицающего страсть к наживе.

Поскольку представления в исламе о роли и функциях банков не совпадают с реальной ситуацией в международном банковском деле - элементе финансовой системы мирового хозяйства сегодня, возникла объективная необходимость в адаптировании норм шариата к формам и методам банковских операций. Как отмечалось выше, исламская банковская система запрещает взятие «рибаа» (ссудного процента), поскольку шариат рассматривает это как прибыль, полученную без приложения производственных усилий ${ }^{5}$.

Но все дело в том, что исламские банки не могут быть полноценными участниками современного международного ссудного

\footnotetext{
4 Там же.

5 Жданов Н. В. Исламская концепция миропорядка.- М.: Междунар. Отношения, 2003.-318 с.
} 
рынка, во всяком случае в открытых формах, так как формальный запрет на взимание процентов не позволяет начислять соответствующие проценты по межбанковским депозитам и ограничивает их активные операции финансированием внешней торговли, операциями на денежном рынке и рынке золота.

В этих условиях наблюдается избыток ликвидности банков. Складывается впечатление, что сами банки призваны быть финансовыми институтами «Исламской солидарности», а не участвовать активно в международных финансовых операциях.

Многие граждане в России, тешащие себя иллюзиями получения исламской банковской благодати в период экономического кризиса не знают о том, что кроме финансово-экономической деятельности, Исламский банк развития осуществляет и своеобразную политическую деятельность.

Речь идет о предоставлении «помощи мусульманским общинам», которые получают серьезную финансовую и политическую поддержку со стороны исламских государств, и которые видят в диаспорах не только проводников своих интересов внутри ЕС, но и направление практической реализации концепции «исламской солидарности», которая является важнейшим принципом внешней политики этих стран ${ }^{1}$.

Эта помощь осуществляется в виде операций по предоставлению специальной помощи (Special Assistance Operations) в рамках двух видов программ в интересах мусульманских общин в государствах - не членах ИБР. Это Программа предоставления специальной помощи (Special Assistance Program)

\footnotetext{
${ }^{1}$ Филь М. С. Мусульманское сообщество в России: проблемы политического участия и социальной адаптации: монография/М. С. Филь. М.: Маркет ДС, 2006. 128 с. (Академическая серия).
}

и Программа предоставления стипендий на обучение и подготовку кадров (Scholarship Program).

Программа предоставления специальной помощи была учреждена в 1980 году. Основными ее целями являются:

1) содействовать убыстрению экономического развития и социального прогресса мусульманских общин в странах — не членах ИБР по всему миру;

2) предоставлять помощь и оказывать содействие государствам-членам и мусульманским общинам в случае природных бедствий и голода;

3) облегчать участь мусульманских беженцев по всему миру.

С начала своего осуществления программа предоставления специальной помощи мусульманским общинам в государствах не членах была направлена, как утверждается в докладах ИБР, на развитие и укрепление институтов в сфере образования, здравоохранения и социальной деятельности в целях улучшения уровня жизни и сохранения исламской самобытности мусульманских общин ${ }^{2}$.

Можно констатировать, что многие идеологи единства исламского мира стремятся превратить мусульманские общины, проживающие на территории неисламских государств, в инструмент исламизации светских обществ.

В этой связи еще более возрастает значение технологий разносторонней интеграции членов исламских общин в жизнь секуляризованных государств ${ }^{3}$.

\footnotetext{
2 Жданов Н. В. Исламская концепция миропорядка. М.: Международные отношения, 2003.— 434 с.

${ }^{3}$ Филь М. С. Мусульманское сообщество в России: проблемы политического участия и социальной адаптации: монография/М. С. Филь. М.: Маркет ДС, 2006. 128 с. (Академическая серия).
} 
Хорошо известно, что не только национал-сепаратисты внутри России, но и многие зарубежные организации пантюркистской и панисламистской направленности активно способствовали усилению политической активности российских мусульман и ее переводу в деструктивное русло, разыгрывая карту наднациональной «исламской солидарности».

Не будем забывать, что движение «Исламская солидарность», будучи модифицированной формой панисламизма, является реальностью современной мировой политики. В ее основе - концепция «Уммы» ${ }^{1}$.

Такой концепции нет ни в одной религии, ни в одном философском учении, хотя отдельные элементы, безусловно, являются результатом взаимодействия ведущих мировых религий.

В понятие «Уммы» вкладывается единство мировоззрений и действий всех мусульман, основанное на братской любви, терпимости, взаимном уважении и способности понимать других.

«Исламское братство» стирает государственные границы, разницу между черными и белыми, азиатами и африканцами. Принцип такого братства положен в основу исламской концепции мирового порядка² ${ }^{2}$

Ислам - не просто религия.

Современная светская мысль недооценивает исламскую идентичность, тогда как для мусульманина отречение от веры - не просто религиозный, а политико-юридический акт. Принадлежность к умме важнее для мусульманина, чем гражданство в том или ином государстве. Это недвусмысленно выразил один молодой англичанин, принявший ислам: «Я не англи-

\footnotetext{
1 Жданов Н. В. Исламская концепция миропорядка. М.: Международные отношения, 2003.-434 с.

2 Там же.
}

чанин-мусульманин, а мусульманин, живущзий в Англии» ${ }^{3}$. Поэтому европейские государства не должны рассматривать обращение своих граждан в ислам как просто осуществление духовного выбора: встает реальная проблема суверенитета ${ }^{4}$.

И это может привести к печальным для всех нас последствиям, т.к. вся история ислама свидетельствует, что как его отношение к иноверцам, так и способы исламизации населения постоянно изменялись в зависимости от конкретных социальнополитических, экономических и прочих условий. Однако «во все времена цуентральной и доминирующей идеей ислама в отношении к немусульманам была идея превосходства мусульман над ними, а общей тенденцией развития этих отношений - обращение их на путь «истинной» религии с применением самых различных форм и методов, начиная от мирных, добровольных и кончая насильственными» ${ }^{5}$.

В 1975 году членами ИБР были 22 государства, к концу 2000 года в состав участников Банка входили 54 государства.

Многие эксперты, рекламирующие в России деятельность ИБР, забывают (либо сознательно скрывают!) главное, что он выступает в качестве действенного инструмента влияния и давления в зоне распространения ислама в целях реализации концепции исламского мирового порядка.

\footnotetext{
${ }^{3}$ Дель Валь А. Исламизм и Соединенные Штаты: Союз против Европы DEL VALLE A. Islamisme et Etats-Unis: Une alliance contre I'Europe.- - Lausanne: L'Age d'Homme, 1999. - 360 р. (Книга французского исследователя А. дель Валя посвящена совместному наступлению на интересы Европы двух весьма разных сил - мирового исламизма и США).

4 Там же.

5 Вагабов М.В., Вагабов Н.М. Ислам и вопросы атеистического воспитания: Учеб. Пособие для вузов.- М.: Высшая школа, 1988.- 70.
} 
Так что же, новый исламский мировой экономический порядок - мираж или приманка для наиболее отсталых стран зоны распространения ислама в целях их удержания в орбите движения «Исламская солидарность»?

Да, по своим реальным возможностям ИМЭП - экономический мираж, поскольку ни одна из стран - участниц движения «Исламская солидарность» не обладает современной развитой промышленной и научно-технологической базой на комплексной основе, а вся зона распространения ислама продолжает оставаться зависимой от развитых западных государств.

Избыточные финансовые средства, которые выделяют нефтедобывающие страны на нужды «солидарности» или ИМЭП, зависят, в свою очередь, от ситуации на мировых рынках нефти и нефтепродуктов, а получатели этих средств вынуждены их реализовывать в большинстве случаев на западных рынках технологий${ }^{1}$.

Именно поэтому, исламская модель экономики и международных экономических отношений не может быть самостоятельной и эффективной.

Скорее исламская модель - это своеобразная идеологическая игрушка для ее создателей и приманка для тех мусульманских стран, которые еще колеблются в отношении исламизации своей общественной жизни ${ }^{2}$.

Подводя итоги в своей статье, необходимо отметить, что реализация концепции исламского мирового порядка угрожает светским принципам миропонимания и светскому праву в России, т. к. может нанести непоправимый ущерб гражданскому обществу и демократии в России.

\footnotetext{
${ }^{1}$ Жданов Н.В. Исламская концепция миропорядка.- М.: Междунар. Отношения, 2003._- 347 с.

${ }^{2}$ Там же.
}

Цензура на отдельные элементы культурного наследия, дискриминация сообществ с иным мировоззрением, строительство религиозных сооружений в ущерб комфорту местных жителей и инфраструктуре района, введение обязательных религиозных предметов в государственных школах, масштабные государственные преференции отдельным религиозным организациям - тревожные симптомы, ведущие к нарушению прав человека и гражданина, закрепленных в светской Конституции РФ, и создающие угрозу внутренней безопасности государства.

Публичные жертвоприношения или издевательства над гражданами, не желающими одеваться по исламским канонам или соблюдать мусульманский пост, основаны на том же самом процветающем в исламской среде убеждении, что религиозные нормы выше законов государства.

Сегодня уже можно констатировать, что многие сторонники идеи глобального исламского мира посредством радио, телевидения, печати и личных контактов стремятся подогреть религиозно-националистические чувства мусульман в России, гальванизировать идею «святости» мусульманского вероучения.

Острота идеологической конфронтации в современном мире обязывает научных исламоведов исключить нейтралитет и компромиссы в мировоззренческой области, облюбованной противниками социального прогресса ${ }^{3}$.

Таким образом, духовная безопасность является неотъемлемой частью национальной и конституционной безопасности, где свобода совести является основой свободы как таковой в рамках демократического правового государства, где никакая религия не может быть устойчивой идеологической платформой

\footnotetext{
${ }^{3}$ Петраш Ю.Г., «Культ святых в исламе», издательство «LAP LAMBERT Academic Publishing», Берлин, 2012.
} 
для объединения людей, a, наоборот, станет источником раздора и противоборства.

Но в атмосфере современной России в любом случае это будет сопровождаться нападками на свободомыслие и атеизм, столь ненавистные всем традиционным религиям. Никогда не было и не может быть мира под оливами любых религий, а если он есть, то это мир забитости, смирения покорных, мир духовной неволи.

\section{Подведем итоги:}

Современные верхи мусульманского духовенства в зарубежных странах и в России стараются любыми способами расширить границы влияния ислама и углубить его на самые основы любых госструктур.

В этом стоит попытка исламизации всего мира. К сожалению этого недопонимают правительственные круги РФ, либо сознательно ведут дело на развал РФ и утверждения принципа конфедеративного устройства.

Одной из претензий на мировое господство ислама является вторжение его в основы экономической жизни РФ. Издесь принцип разделения по отношению к религии налицо. Экономическая банковская система в ее отдельной части получила название «исламский банкинг». При этом цели исламской «аннексии» на основы экономической жизни РФ маскируются с виду безвинным принципом некой исламской принадлежности.

Еще К. Маркс указывал, что капитал не знает отечества и патриотизма. Патриотизм там, где вложен капитал, и попытки проникновения исламского капитала в РФ имеют дальний прицел:

во-первых, активизировать частный сектор, находящийся в руках мусульман. А это значит, реально будут сталкиваться интересы мусульман с немусульманским предпринимательством, и тогда это будет чревато столкновениями, которые будут прикрываться конфессиональной принадлежностью. На выручку мусульманским предпринимателям и банкирам немедленно придут мусульманские миллиардеры из-за рубежа, в особенности из стран арабского мира, которые наживают на нефти сказочные богатства. Именно эти мультимиллиардеры, защищая капиталы мусульман, станут вмешиваться в российские общественно-государственные структуры и будут финансировать незаконные вооруженные формирования, а также оказывать соответствующее идеологическое влияние, размывая единство многонационального российского народа.

Есть опасность и в том, что заинтересованные в укреплении своих финансовоэкономических позиций станут принимать ислам граждане РФ.

Bo-вторых, укрепление финансового рынка со стороны ислама будет подрывать положение соответствующих экономических кругов России.

А это и станет тем, что называется «тихой экспансией иностранного капитала» и вживания его в национальную экономику с целью подрыва экономического положения России.

\section{Библиография}

1. http://www.muslimeco.ru/opubl/54/

2. См. например статью ведущего научного сотрудника НИИ Академии Генеральной прокуратуры РФ Е. В. Быковой «Ислам, мусульманское право и общечеловеческие ценности» (журнал «Международное публичное и частное право», М., 2010. № 4).

3. См. например: Зыкова С. В. Связь религиозного и правового сознания / С. В. Зыкова // История государства и права. 2006. — № 9.— С.17-19.Корнев В.Н., Проблемы теории пра- 
восознания в современной отечественной юриспруденции. История государства и права № 20-2009., Ковалев С. А. Деформация правосознания как фактор противоправного поведения личности / С. А. Ковалев // История государства и права.—2009.- N 13.— С.35-37., Марченя, П. П. Массовое правосознание как фактор русской революции 1917 г. / Марченя П. П. // История государства и права.-2010.- N 19.— С. 20-22. Право - Общая теория права.

4. Тонконогов А. В., автореферат диссертации на диссертации на соискание учёной степени доктора философских наук «Духовная безопасность российского общества в условиях современного геополитического соперничества (социально-философский анализ), М.:, 2011.

5. Бернард Льюис, Кризис ислама, «Bedek Media Ltd.», издание на русском языке, 2007

6. Жданов Н. В. Исламская концепция миропорядка.- М.: Междунар. Отношения, 2003.—317 c.

7. Лабевьер Р. Доллары террора: Соединенные штаты и исламисты (LABEVIERE R. Les dollars de la terreur: Les Etats-Unis et les islamistes.— P.: Bernard Grasset, 1999.—439 p. (Книга главного редактора «Radio France Internationale» посвя ᄀщена подъему исламизма в мире в 90-е годы и роли в нем ЦРУ США).

8. Там же.

9. Там же

10. Piscatori J. P. Islamic Values and National Interest: The Foreign Policy of Saudi Arabia // Islam in Foreign Police.- London: Cambridge University Press, 1983.- P.33.

11. Валькова Л. В. Саудовская Аравия в международных отношениях-М. Наука, 1979.— С. 165.

12. Жданов Н. В. Исламская концепция миропорядка.-М.: Междунар. Отношения, 2003.-318 c.

13. Филь М. С. Мусульманское сообщество в России: проблемы политического участия и социальной адаптации: монография/М. С. Филь. М.: Маркет ДС, 2006. 128 с. (Академическая серия).

14. Жданов Н. В. Исламская концепция миропорядка. М.: Международные отношения, 2003. - $434 \mathrm{c}$.

15. Дель Валь А. Исламизм и Соединенные Штаты: Союз против Европы DEL VALLE A. Islamisme et Etats-Unis: Une alliance contre I'Europe.- Lausanne: L'Age d'Homme, 1999. - 360 р. (Книга французского исследователя А. дель Валя посвящена совместному наступлению на интересы Европы двух весьма разных сил-мирового исламизма и США).

16. Вагабов М.В., Вагабов Н. М. Ислам и вопросы атеистического воспитания: Учеб. Пособие для вузов.- М.: Высшая школа, 1988.-70.

17. Жданов Н.В. Исламская концепция миропорядка.-М.: Междунар. Отношения, 2003 - 347 с.

18. Петраш Ю. Г., «Культ святых в исламе», издательство «LAP LAMBERT Academic Publishing», Берлин, 2012.

19. Д. Ю. Базаркина Корни этнорелигиозного терроризма в Европейском Союзе и Латинской Америке: общее и особенное // Международные отношения._-2012._- 1.— С. 54-59.

\section{References (transliterated)}

1. http://www.muslimeco.ru/opubl/54/

2. Sm. naprimer stat'yu vedushchego nauchnogo sotrudnika NII Akademii General'noi prokuratury RF E. V. Bykovoi «Islam, musul'manskoe pravo i obshchechelovecheskie tsennosti» (zhurnal «Mezhdunarodnoe publichnoe i chastnoe pravo», M., 2010. № 4). 
3. Sm. naprimer: Zykova S. V. Svyaz» religioznogo i pravovogo soznaniya / S. V. Zykova //Istoriya gosudarstva i prava. 2006.- № 9.- S.17-19.Kornev V.N., Problemy teorii pravosoznaniya v sovremennoi otechestvennoi yurisprudentsii. Istoriya gosudarstva i prava № 20-2009., Kovalev S. A. Deformatsiya pravosoznaniya kak faktor protivopravnogo povedeniya lichnosti / S. A. Kovalev // Istoriya gosudarstva i prava. - 2009. - N 13.- S.35-37., Marchenya, P. P. Massovoe pravosoznanie kak faktor russkoi revolyutsii 1917 g. / Marchenya P. P. // Istoriya gosudarstva i prava.-2010.- N 19.- S. 20-22. Pravo - Obshchaya teoriya prava.

4. Tonkonogov A. V., avtoreferat dissertatsii na dissertatsii na soiskanie uchenoi stepeni doktora filosofskikh nauk «Dukhovnaya bezopasnost» rossiiskogo obshchestva v usloviyakh sovremennogo geopoliticheskogo sopernichestva (sotsial'no-filosofskii analiz), M.:, 2011.

5. Bernard L’yuis, Krizis islama, «Bedek Media Ltd.», izdanie na russkom yazyke, 2007

6. Zhdanov N. V. Islamskaya kontseptsiya miroporyadka.- M.: Mezhdunar. Otnosheniya, 2003.$317 \mathrm{~s}$.

7. Labev'er R. Dollary terrora: Soedinennye shtaty i islamisty (LABEVIERE R. Les dollars de la terreur: Les Etats-Unis et les islamistes.— P.: Bernard Grasset, 1999.—439 p. (Kniga glavnogo redaktora «Radio France Internationale» posvya $\neg$ shchena pod"emu islamizma v mire v 90-e gody i roli v nem TsRU SShA).

8. Tam zhe.

9. Tam zhe

10. Piscatori J. P. Islamic Values and National Interest: The Foreign Policy of Saudi Arabia // Islam in Foreign Police.- London: Cambridge University Press, 1983.- R.33.

11. Val'kova L. V. Saudovskaya Araviya v mezhdunarodnykh otnosheniyakh-M. Nauka, 1979. — S. 165.

12. Zhdanov N. V. Islamskaya kontseptsiya miroporyadka.—-M.: Mezhdunar. Otnosheniya, 2003.$318 \mathrm{~s}$.

13. Fil» M. S. Musul'manskoe soobshchestvo v Rossii: problemy politicheskogo uchastiya i sotsial'noi adaptatsii: monografiya/M. S. Fil». M.: Market DS, 2006. 128 s. (Akademicheskaya seriya).

14. Zhdanov N. V. Islamskaya kontseptsiya miroporyadka. M.: Mezhdunarodnye otnosheniya, 2003. - $434 \mathrm{~s}$.

15. Del» Val» A. Islamizm i Soedinennye Shtaty: Soyuz protiv Evropy DEL VALLE A. Islamisme et Etats-Unis: Une alliance contre I'Europe.- Lausanne: L'Age d'Homme, 1999.-360 p. (Kniga frantsuzskogo issledovatelya A. del» Valya posvyashchena sovmestnomu nastupleniyu na interesy Evropy dvukh ves'ma raznykh sil-mirovogo islamizma i SShA).

16. Vagabov M. V., Vagabov N. M. Islam i voprosy ateisticheskogo vospitaniya: Ucheb. Posobie dlya vuzov.- M.: Vysshaya shkola, 1988. - 70 .

17. Zhdanov N. V. Islamskaya kontseptsiya miroporyadka.—M.: Mezhdunar. Otnosheniya, 2003.$347 \mathrm{~s}$.

18. Petrash Yu.G., «Kul’t svyatykh v islame», izdatel'stvo «LAP LAMBERT Academic Publishing», Berlin, 2012.

19. D. Yu. Bazarkina Korni etnoreligioznogo terrorizma v Evropeiskom Soyuze i Latinskoi Amerike: obshchee i osobennoe // Mezhdunarodnye otnosheniya._ 2012._ 1._ C. 54-59. 